\title{
PENERAPAN UNSUR TINDAK PIDANA PERSETUBUHAN TERHADAP ANAK YANG DISEBARKAN MELALUI MEDIA SOSIAL PADA PENYIDIKAN
}

\author{
${ }^{1)}$ Jeki Noviardi, ${ }^{2)}$ Fitriati, ${ }^{3)}$ Herman Bakir \\ ${ }^{1)}$ Program Magister Ilmu Hukum,Universitas Ekasakti, Padang, Indonesia \\ Email: jekiebj@yahoo.com \\ ${ }^{2)}$ Universitas Ekasakti, Padang, Indonesia \\ Email: izidanhalim@gmail.com \\ ${ }^{3)}$ Universitas Borobudur, Jakarta, Indonesia \\ Email: hermanbakir@gmail.com
}

\begin{abstract}
Investigators' considerations at the Kerinci Police Satreskrim in the application of elements of the crime of sexual intercourse against children broadcast through social media is to only apply the elements contained in Article $76 D$ in conjunction with Article 81 Paragraph (1) of RI Law No. 35 of 2014, concerning changes to Law of the Republic of Indonesia Number 23 of 2002 concerning Child Protection and does not consider the act of recording and spreading the act of sexual intercourse on social media. This is done by considering the cost of proof and also the initial consideration of the suspect who is still young so that it is hoped that his behavior will improve. Obstacles encountered by investigators at the Kerinci Satreskrim Polres in the application of the non-crime of sexual intercourse against children broadcast through social media are obstacles that involve human resources of investigators. Investigators who do not understand the material of the child protection law that has been made, namely Law number 35 of 2014 concerning amendments to law number 23 of 2002 concerning child protection in terms of applying the electronic transaction information law because the act was recorded which then disseminated. However, in this investigation, the investigator did not apply the elements contained in the ITE legislation. Evidence investigators because of difficulties in collecting evidence and testing the correctness of the tool.
\end{abstract}

Keywords: Child, Sexual intercourse, Investigation, Social Media

\begin{abstract}
ABSTRAK
Pertimbangan Penyidik Pada Satreskrim Polres Kerinci Dalam Penerapan Unsur Tindak Pidana Persetubuhan Terhadap Anak Yang Disiarkan Melalui Media Sosial adalah dengan hanya menerapkan unsur yang terdapat pada Pasal 76D jo Pasal 81 Ayat (1) Undang-undang RI No 35 tahun 2014, tentang perubahan atas Undang-Undang RI Nomor 23 Tahun 2002 Tentang Perlindungan Anak dan tidak mempertimbangkan perbuatan terdakwa merekam dan menyebar luaskan perbuatan persetubuhan tersebut dalam media sosial. Hal ini dilakukan dengan pertimbangan tingginya biaya pembuktian dan juga pertimbangan usia tersangka yang masih muda sehingga diharapkan dapat memperbaiki prilakunya. Kendala Yang Ditemui Penyidik Pada Satreskrim Polres Kerinci Dalam Penerapan Unsur Tindak Pidana Persetubuhan Terhadap Anak Yang Disiarkan Melalui Media sosial adalah hambatan yang menyangkut segi sumber daya manusia dari penyidik. Penyidik yang kurang memahami materi undang undang perlindungan anak yang telah diperbaharui yaitu Undang undang nomor
\end{abstract}


35 tahun 2014 tentang perubahan atas undang undang nomor 23 tahun 2002 tentang perlindungan anak juga dalam hal menerapkan undang undang informasi transaksi elektronik karena perbuatan tersebut direkam yang kemudian disebar luaskan. Namun dalam penyidikan ini penyidik sama sekali tidak menerapkan unsur unsur yang terdapat dalam perundang undangan ITE tersebut. Penyidik beralasan karena adanya kesulitan dalam hal pengumpulan bukti dan pengujian kebenaran alat bukti.

Kata Kunci: Anak, Persetubuhan, Penyidikan, Media Sosial

\section{PENDAHULUAN}

Upaya perlindungan hukum terhadap anak telah cukup lama dibicarakan baik di indonesia maupun di dunia Internasional. Pembicaraan mengenai hal ini tidak akan berhenti, karena selain merupakan masalah universal, juga karena di dunia ini akan selalu di hiasi oleh anak-anak. Selama dunia tidak sepi oleh anak-anak, sepanjang itulah masalah anak akan selalu dibicarakan. ${ }^{1}$

Problematika berkenaan dengan tindak pidana asusila terhadap anak timbul karena hukuman penjara yang diberikan kepada pelaku tidak membuat orang-orang takut melakukan hal tersebut, malah semakin banyak pelaku tindak pidana perkosaan dan pencabulan terhadap anak. $^{2}$ Salah satu perbuatan yang dilarang oleh hukum pidana adalah pencabulan. Kitab Undang-Undang Hukum Pidana (Selanjutnya disebut KUHP) menggolongkan tindak pidana pencabulan ke dalam tindak pidana kesusilaan. KUHP belum mendefinisikan dengan jelas maksud dari pencabulan itu sendiri dan terkesan mencampur adukkan pengertiannya dengan perkosaan atau persetubuhan. Pencabulan merupakan salah satu dari kejahatan seksual yang diakibatkan dari adanya perubahan yang terjadi dalam struktur masyarakat kita. Pencabulan adalah jenis kejahatan yang berdampak sangat buruk terutama pada korbannya, sebab pencabulan akan melanggar hak asasi manusia serta dapat merusak martabat kemanusiaan, khususnya terhadap jiwa, akal dan keturunan. Kasuskasus tindak pidana pencabulan saat ini marak terdengar terjadi di Indonesia. Korban dalam kejahatan ini seringkali adalah anak-anak.

Berita mengenai persetubuhan anak yang sedang maraknya terdengar yaitu, mengenai persetubuhan anak yang bermula dari perkenalan lewat situs jejaring sosial yang di kenal dengan nama Facebook. Undang-Undang Nomor 23 Tahun 2002 tentang Perlindungan Anak mengamati pemberian perlindungan khusus bagi anak yang berhadapan dengan hukum. Dalam Pasal 64 ayat (1) di sebutkan bahwa perlindungan khusus bagi anak yang berhadapan dengan hukum meliputi anak yang berkonflik dengan hukum dan anak korban tindak pidana, merupakan kewajiban dan tanggung jawab masyarakat. Terhadap tindak pidana persetubuhan terhadap harus dilakukan penyidikan. Guna hal ini penyidik harus dapat secara tepat menerapkan unsur unsur pidana terhadap tindak pidana yanng dilakukan.

Seperti Tindak pidana persetubuhan yang terjadi di wilayah hukum Polres Kerinci dengan Laporan Polisi Nomor : LP / B-348/ VI/ 2019 / SPKT.1/ RES KRC, tanggal 13 Juni 2019. Dimana perbuatan persetubuhan tersebut dilakukan terhadap anak dan kemudian video serta foto adegan persetubuhan tersebut disebarkan melalui media Sosial. Satreskrim Polres

\footnotetext{
${ }^{1}$ Apong Herlina, Perlindungan terhadap Anak yang Berhadapan dengan Hukum, Buku Saku untuk Polisi, Unicef, Jakarta, 2004, hlm. 6

${ }^{2}$ Wahyuningsih, S. E., Perlindungan Hukum Terhadap Anak Sebagai Korban Tindak Pidana Kesusilaan Dalam Hukum Pidana Positif Saat Ini, Jurnal Pembaharuan Hukum, III (2), 2016, hlm. 172-180.
} 
Kerinci pada tahap penyidikan berusaha untuk memutuskan unsur pasal yang akan disangkakan. Dilema bagi penyidik adalah akan menerapkan unsur tindak pidana persetubuhan menurut Undang undang perlindungan anak ataukan unsur tindak pidana yang terdapat pada undang undang informasi transaksi elektronik (ITE) Pertimbangan pertimbangan dilakukan untuk menerapkan unsur unsur tindak pidana yang telah dilakukan oleh tersangka.

Permasalahan yang dibahas adalah penerapan unsur tindak pidana persetubuhan terhadap anak yang disiarkan melalui media sosial oleh Satreskrim Polres Kerinci.

\section{METODE PENELITIAN}

Spesifikasi penelitian adalah deskriptif analitis, dengan metode pendekatan yuridis normative didukung oleh yuridis empiris. Jenis data yang digunakan adalah data sekunder dan data primer. Data sekunder diperoleh dari studi dokumen, data primer diperoleh dengan cara wawancara. Data yang diperoleh kemudian dianalisa secara kualitatif.

\section{PEMBAHASAN}

\section{A. Pertimbangan Penyidik Pada Satreskrim Polres Kerinci Dalam Penerapan Unsur} Tindak Pidana Persetubuhan Terhadap Anak Yang Disiarkan Melalui Media Sosial

Secara normatif, telah diatur mengenai tindak pidana persetubuhan terhadap anak di dalam Kitab Undang-undang Hukum Pidana, yakni Pasal 287 KUHP, yang rumusan aslinya berbunyi sebagai berikut: ${ }^{3}$

(1) Hij die buiten echt vleselijk gemeenschap heeft met ene vrouw van wie hij weet of redelijkerwijs moet vermoeden dat zij indien van haar leeftijd niet blijkt, nog niet huwbaar is, wordt gestraft met gevangenisstraf van ten hogste negen jaren (Penuntutan tidak akan dilakukan apabila tidak ada pengaduan, kecuali jika wanita tersebut belum mencapai usia dua belas tahun atau jika terjadi hal-hal seperti yang diatur dalam Pasal 291 dan Pasal 294. )

Secara umum pelaku melakukan tindak pidana persetubuhan dengan cara seduksi (Seduire: membujuk, menggoda) dan perkosaan. Seduksi merupakan bujukan dan godaan untuk mengajak partnernya bersetubuh, yang sebenarnya melanggar norma susila atau melanggar hukum. Biasanya wanita mendapatkan janji-janji indah akan dikawini dan ditanggung nasibnya. Hubungan seksual antara orang dewasa dan anak walaupun dilakukan tidak dengan cara mengancam atau memaksa secara hukum tindakan tersebut masuk dalam kategori tindak pidana pemerkosaan terhadap anak (statutory rape). Demikian juga halnya dengan yang terjadi di wilayah hukum Polres kerinci, dimana persetubuhan terhadap anak yang dilakukan dengan menjanjikan akan bertanggung jawab dan lain sebagainya.

Kedekatan hubungan antara lawan jenis (laki-laki dengan perempuan yang bukan istrinya atau bukan mahramnya) merupakan faktor yang cukup berpengaruh terhadap terjadinya kejahatan seksual. Pihak pelaku memang bersalah, namun kesalahan yang diperbuat itu bisa disebabkan oleh kesalahan kesalahan yang secara tidak langsung

${ }^{3}$ P.A.F Lamintang dan Theo Lamintang, Delik-delik Khusus Kejahatan Melanggar Norma Kesusilaan dan Norma Kepatutan(Edisi Kedua), Sinar Grafika,Jakarta, 2011, hlm.113 
diperbuat oleh korban. ${ }^{4}$ Persetubuhan yang dilakukan oleh pelaku terhadap anak sebagai korban pada umumnya, akibat motivasi berpacaran atau percintaan dan beberapa di antaranya berorientasi pada pemuasan nafsu serta kebebasan seksual untuk mencapai kepuasan.

Adapun unsur yang terpenuhi berdasarkan alat bukti yang terkumpul adalah unsur subyektif yaitu unsur perbuatan yang dilakukan oleh manusia. Unsur subyektif disini adalah Unsur Setiap Orang. Maksud dari unsur setiap orang adalah sebagai subjek hukum yang kepadanya dapat di pertanggungjawabkan perbuatannya. Unsur ini terpenuhi berdasarkan keterangan para saksi dan petunjuk serta pengakuan tersangka. Keterangan beberapa orang saksi menyatakan bahwa yang dapat mempertanggung jawabkan perbuatannya adalah seorang laki laki yang sudah berumur 21 tahun. Tersangka dalam pemeriksaannya telah menunjukan kecakapan dan kemampuan di mana tersangka mempunyai fisik dan psikis yang sehat, sehingga dapat mempertanggungjawabkan perbuatannya dan tidak adanya unsur pemaaf dan pembenar dari perbuatan tersebut.

Unsur kedua adalah unsur obyektif yaitu unsur perbuatan yang dilakukan. Adapun unsur obyektif adalah "Dilarang Melakukan Kekerasan Atau Ancaman Kekerasan Memaksa Anak". Unsur yang melakukan kekerasan atau ancaman kekerasan memaksa anak telah terpenuhi berdasarkan Alat bukti keterangan saksi korban yang menerangkan bahwa tersangka telah melakukan pemaksaan untuk melakukan persetubuhan dengan membuka paksa pakaian korban walaupun sudah dilarang oleh korban.

Setelah kejadian tersebut tersangka pernah meminta Korban untuk mengirimkan Foto nampak payudara Korban, dan saat itu Korban ada mengirimkannya dengan tersangka. Sekitar beberapa bulan kemudian tersangka kembali bertemu Korban. Saat itu tersangka menyuruh Korban membuka celana dan Korban mengatakan "buka celana kamu, dan Korban menjawab "tidak mau" kemudian tersangka mengatakan "buka saja, kalau tidak mau nanti Foto kamu aku sebar" dan saat itu Korban takut dan mengikuti saja kemauan tersangka tersebut dan Korban membuka baju dan celana Korban dan tersangka melakukan tindakan persetubuhan terhadap korban. Namun dalam penerapan unsur oleh penyidik tidak menerapkan perbuatan tersangka yang merekam dan menyebar luaskan rekaman persetubuhan tersebut.

Unsur terhadap Anak telah terpenuhi berdasarkan Alat Bukti dari keterangan saksi saksi lain, Saksi petunjuk dan Tersangka menerangkan bahwa korban masih berumur 17 tahun 4 Bulan, berdasarkan angka kelahiran korban masih dikategorikan sebagai anak.

Unsur Melakukan Persetubuhan Dengannya Atau Dengan Orang Lain telah terpenuhi berdasarkan Alat Bukti keterangan saksi korban yang menerangkan perbuatan persetubuhan yang dilakukan tersangka terhadap dirinya. Tersangka juga memvideokan adegan tersebut. Kemudian sekitar beberapa hari setelah kejadian tersebut, Korban diberitahu oleh Teman Korban an dan memperlihatkan video tersebut, dan saat itu Korban baru mengetahui bahwa Video Korban telah disebar oleh tersangka. Persetubuhan yang terjadi juga dibuktikan dengan surat visum yang menyatakan "Tidak Ada TandaTanda Trauma Pada Alat Kelamin Luar, Robekan Hymen Pada Posisi Jam, 2, Jam 9 Dan 11, Hymen Tidak Utuh".

${ }^{4}$ Abdul Wahid dan Muhammad Irfan, Perlindungan Terhadap Korban Kekerasan Seksual (Advokasi atas Hak Asasi Perempuan), Refika Aditama, Bandung, 2011, hlm.69 
Unsur perbuatan pidana telah terpenuhi berdasarkan alat bukti yang dikumpulkan oleh penyidik dan tersangkalah pelakunya serta kesalahan ada padanya sehingga patut untuk di proses lebih lanjut dalam peradilan pidana. Adanya kontribusi saksi korban sehingga tindak pidana persetubuhan itu terjadi merupakan kondisi yang harus memberikan sedikit "keuntungan" bagi tersangka karena bagaimanapun perbuatan saksi korban berupa memasuki kamar tersangka dan kemudian hanya dipaksa dengan bujuk rayu saja dapat memilih antara melakukan persetubuhan atau tidak melakukan persetubuhan, tetapi memilih untuk bersetubuh adalah perbuatan yang tercela karenanya ada kesalahan korban walaupun dalam tingkat yang mungkin sangat kecil. Sementara perbuatan menyebar luaskan video persetubuhan tersebut dikesampingkan oleh penyidik karena dengan pertimbangan tingginya biaya pembuktian dan juga pertimbangan usia tersangka yang masih muda sehingga diharapkan dapat memperbaiki prilakunya.

\section{B. Kendala Yang Ditemui Penyidik Pada Satreskrim Polres Kerinci Dalam Penerapan Unsur Tindak Pidana Persetubuhan Terhadap Anak Yang Disiarkan Melalui Media Sosial}

Masalah kekerasan seksual khususnya persetubuhan terhadap anak perlu mendapat perhatian lebih intensif dan serius lagi. Hal ini mengingat, terdapat kecenderungan bahwa korban anak sering terabaikan oleh lembaga-lembaga kompoten dalam sistem peradilan pidana, yang seharusnya memberikan perhatian dan perlindungan yang cukup berdasarkan hukum. Hal tersebut tidak seharusnya terjadi, sebab bagaimanapun korban tetap mempunyai hak untuk diperlakukan adil.

Upaya penanganan hukum dalam proses perlindungan anak terkait kasus tindak pidana persetubuhan juga dilakukan oleh pihak-pihak penegak hukum diantaranya kepolisian yang salah satunya adalah Kepolisian Resort Kerinci, Jambi. Berdasarkan hasil penelitian yang telah dilakukan, pihak kepolisian di Polres Kerinci khususnya unit Perlindungan Perempuan dan Anak (PPA) telah menangani beberapa kasus terkait dengan persetubuhan terhadap anak. Pada umumnya pelaku adalah orang yang mempunyai hubungan khusus dengan korban atau berpacaran. Jumlah kasus tindak pidana persetubuhan terhadap anak yang terjadi selama tiga tahun terakhir mencapai 33 kasus. Maraknya kasus tindak pidana persetubuhan terhadap anak yang terjadi di wilayah hukum Polres Kerinci merupakan salah satu bukti bahwa penanganan hukum dan perlindungan terhadap anak yang terjadi di Indonesia khususnya di Kerinci belum begitu akurat dilakukan.

Salah satu bentuk tindakan hukum yang dilakukan untuk melindungi anak sebagai korban tindak pidana persetubuhan adalah dengan melakukan penyidikan. Dalam melakukan penyidikan tindak pidana persetubuhan dan pencabulan terhadap anak, penyidik menemui hambatan-hambatan atau kendala. Hal ini berdasarkan wawancara dengan Penyidik dan Penyidik Pembantu di Polres Kerinci. Adapun hambatan yang menyangkut segi sumber daya manusia dari penyidik. Hal ini merupakan hambatan yang paling penting dan yang paling utama dari penyidik yang kurang memahami materi undang undang perlindungan anak yang telah diperbaharui yaitu Undang undang nomor 35 tahun 2014 tentang perubahan atas undang undang nomor 23 tahun 2002 tentang perlindungan anak juga dalam hal menerapkan undang undang informasi transaksi 
elektronik karena perbuatan tersebut direkam yang kemudian disebar luaskan. Namun dalam penyidikan ini penyidik sama sekali tidak menerapkan unsur unsur yang terdapat dalam perundang undangan ITE tersebut. Penyidik seakan tidak mengetahui adanya perbuatan penyebarluasan perbuatan persetubuhan yang dilakukan melalui media sosial tersebut. Berdasarkan hasil wawancara penyidik beralasan karena adanya kesulitan dalam hal pengumpulan bukti dan pengujian kebenaran alat bukti serta pertimbangan usia daripada pelaku dan korban.

Disamping itu pengalaman penanganan terhadap kasus tersebut yang sangat berpengaruh atas keberhasilan dalam pelaksanaan penyidikan kasus tersebut. Kendala yang menyangkut kurangnya pengetahuan penyidik memahami materi perundang undangan terkait sempat menjadi kekhawatiran Unit PPA Saterskrim Polres Kerinci. Di Unit PPA Saterskrim Polres Kerinci hanya memiliki 3 orang penyidik, sedangkan yang seharusnya adalah 7 orang penyidik itupun belum ada yang sarjana. Seandainya pelaku kasus persetubuhan terhadap anak dilakukan oleh orang yang mempunyai pendidikan tinggi dan tahu celah-celah hukum, padahal tenaga penyidik kurang memahami materi dari pasal tersebut yang kemudian akan menyulitkan dalam penanganan penyidikan kasus tindak pidana pencabulan itu. Karena adanya pemikiran tersebut Unit PPA Saterskrim Polres Kerinci, selalu menekankan kepada anggotanya untuk memahami materi pasalpasal dalam KUHP dan perundang undangan khusus lainnya sebelum melakukan penyelidikan atau penyidikan.

Pada perkara ini korban masih anak-anak. Perkara tindak pidana persetubuhan yang terjadi di Unit PPA Saterskrim Polres Kerinci korbannya adalah anak yang masih berumur 17 tahun. Ini merupakan kesulitan bagi penyidik dalam meminta keterangan, karena keterangan yang diberikan berbelit-belit. Tersangka tidak mengaku sebagai pelaku tindak pidana persetubuhan yang terjadi di Unit PPA Saterskrim Polres Kerinci dengan alasan dilakukan secara suka sama suka. Hal ini membutuhkan kerja keras penyidik untuk mengumpulkan bukti bukti tentang perkara ini.

Tidak ada nya saksi yang melihat secara langsung dan saksi tidak mau datang untuk memberikan keterangan. Dalam menyelesaikan perkara membutuhkan saksi untuk mendapatkan keterangan guna mengungkap suatu perkara. Kasus yang terjadi di Unit PPA Saterskrim Polres Kerinci ini tidak ada yang melihat secara langsung kejadiaan pencabulan dan persetubuhan terhadap anak ini. Saksi yang ditunjuk yaitu masyarakat kurang mengetahui hukum. Jadi tidak mau mendatangi Polres untuk memberikan keterangan.

Kendala lainnya adalah keterbatasan Dokter Forensik. Dokter Forensik sangatlah berperan penting untuk mengetahui hasil Visum, namun di Kabupaten Kerinci hanya memiliki satu dokter forensik yang hanya datang hari senin sampai jumat (tidak teratur datangnya). Jika kejadian hari sabtu maka penyidik harus menunggu hari senin untuk visum korban persetubuhan, hasilnya juga keluar seminggu setelah visum.

Kendala dalam pelaksanaan penyidikan lainnya adalah ketika pelaku tindak pidana persetubuhan pada anak mengetahui bahwa dirinya telah dilaporkan oleh korban ke polisi. Pelaku yang telah dilaporkan biasanya akan melarikan diri dan bersembunyi di daerah/kota tertentu sebelum ditangkap oleh penyidik. Penyidik sering mengalami kesulitan dalam mencari si pelaku yang telah melarikan diri dan menjadi buronan tersebut. 
Pihak penyidik dari Unit PPA Saterskrim Polres Kerinci telah melakukan koordinasi dengan Polda Jambi untuk melacak para pelaku dari tindak pidana persetubuhan pada anak yang sering melarikan diri ke seluruh daerah Jambi dan Sumatera Barat. Jika tidak membuahkan hasil yang nyata, maka pihak Polda akan berbagi informasi DPO kepada seluruh Polres yang ada di Indonesia untuk melacak keberadaan pelaku yang melarikan diri tersebut.

Kendala selanjutnya adalah pihak penyidik memiliki keterbatasan waktu dalam memproses berkas dari tindak pidana tersebut. Dengan keterbatasan waktu yang diberikan untuk mengungkap tindak pidana tersebut, pihak penyidik mengalami kesulitan untuk menyelesaikan berkas perkara sesuai target yang ditentukan. Berbeda seperti kasus KDRT yang dapat menyelesaikan berkas perkara sesuai target waktu yang diberikan. Misalnya: untuk berkas dari tindak pidana KDRT target yang diberikan adalah satu bulan akan tetapi berkas tersebut dapat terselesaikan atau terungkap sebelum dari waktu satu bulan. Lain halnya dengan tindak pidana persetubuhan diberikan waktu satu bulan akan tetapi tidak dapat terungkap sebelum dari satu bulan. Berkas tersebut baru dapat selesai atau terungkap setelah beberapa bulan. Hal tersebut dikarenakan jumlah penyidik serta jumlah perkara yang ada tidak seimbang. Saat ini, jumlah personel penyidik yang terdapat di dalam Unit PPA Saterskrim Polres Kerinci adalah hanya 3 (tiga) orang penyidik yang mengungkap tindak pidana persetubuhan pada anak dan dalam kondisi sekarang, satu orang penyidik harus mengungkap sekitar 9-10 Laporan Polisi sehingga penyidik harus bekerja ekstra keras. Jumlah personel tersebut berbanding jauh dengan besar wilayah dari kabupaten Kerinci dan jumlah penduduknya sehingga dalam pelaksanaan pengungkapan tindak pidana persetubuhan terhadap anak masih kurang maksimal.

Kurang mendapatkan informasi tentang si pelaku juga semakin mempersulit pihak penyidik dalam menemukan si pelaku. Pihak penyidik kesulitan melacak keberadaan pelaku yang melarikan diri tanpa mengetahui wajah dan sinyal handphone yang telah tidak aktif. Informasi yang di dapatkan oleh para penyidik hanyalah sekedar informasi seputar ciri-ciri fisiknya, alamat rumah, nomor telepon, keberadaan sementara dari pelaku sehingga penyidik sulit mengetahui secara jelas. Hal tersebut dikarenakan juga banyaknya informasi yang diberikan dari kerabat pelaku, korban, keluarga korban seringkali berbeda dengan hasil penelusuran pihak penyidik di lapangan.

Kendala yang keempat adalah pihak penyidik kesulitan mendapatkan keterangan dari si korban yang memiliki trauma berat. Trauma berat yang dialami seorang anak sangat rentan untuk di minta keterangan atas tindak pidana kekerasan seksual yang dialaminya apalagi yang disebarkan melalui media massa. Dalam penyidikan mengenai tindak pidana persetubuhan pada anak, salah satu langkah penyidik mendapatkan alat bukti dari adanya tindak pidana tersebut pada anak adalah dengan melakukan visum. Dalam pelaksanaannya, tidak ditemukan kesulitan yang sangat memberatkan pihak penyidik, akan tetapi sebagian besar korban beserta keluarganya yang melakukan visum adalah berasal dari keluarga yang kurang mampu dalam hal perekonomian. Pihak korban dan keluarganya sering merasa keberatan umtuk membayar proses visum yang cukup mahal. Pihak korban dan keluarganya yang merasa keberatan adalah keluarga dari korban yang mengalami trauma berat. Visum yang dilakukan mengeluarkan biaya rata-rata sekitar Rp. 60.000 hingga Rp. 300.000 dan belum termasuk obat-obatan yang diterima. Perbedaan 
dalam penentuan tarif dalam melakukan visum sangat tergantung dari pengobatan yang dilakukan. Visum dapat dilakukan di Rumah Sakit Kepolisian setelah pembuatan surat pengantar SPKP yang berdasar kepada Laporan Polisi yang dibuat oleh korban dan keluarganya dan pihak SPKP memproses dengan membuat surat permohonan kepada kepala Rumah Sakit untuk melakukan visum kepada korban tindak pidana tersebut. Apabila tidak terdapat surat permohonan dari SPKP maka hasil visum yang dilakukan oleh korban tidak dianggap sah secara hukum sebagai alat bukti.

Kurangnya sarana dan prasarana yang memadai untuk penyelidikan dan pengungkapan dari tindak pidana persetubuhan pada anak di Unit PPA Saterskrim Polres Kerinci yaitu tempat penyidikan yang sempit, perlengkapan alat-alat kantor yang tidak ditanggung dari pemerintah seperti peralatan komputer, rak lemari untuk menyimpan berkas-berkas serta meja dan kursi sehingga penyidik melakukan swadaya sendiri, adanya penggunaan ruang penyidikan yang kurang maksimal, terbatasnya dana atau biaya untuk menyelidiki sebuah tindak pidana.

\section{KSEIMPULAN}

Peningkatan kemampuan penyidik dalam melakukan penyidikan tindak pidana khusus seperti tindak pidana melalui elektronik dan melakukan koordinasi dengan pihak terkait yang lebih ahli dalam melakukan pembuktian suatu perbuatan melalui media elektronik.

\section{DAFTAR PUSTAKA}

Anak yang Berhadapan dengan Hukum, Buku Saku untuk Polisi, Unicef, Jakarta, 2004

Wahyuningsih, S. E., Perlindungan Hukum Terhadap Anak Sebagai Korban Tindak Pidana Kesusilaan Dalam Hukum Pidana Positif Saat Ini, Jurnal Pembaharuan Hukum, III (2), 2016.

P.A.F Lamintang dan Theo Lamintang, Delik-delik Khusus Kejahatan Melanggar Norma Kesusilaan dan Norma Kepatutan(Edisi Kedua), Sinar Grafika,Jakarta, 2011

Abdul Wahid dan Muhammad Irfan, Perlindungan Terhadap Korban Kekerasan Seksual (Advokasi atas Hak Asasi Perempuan), Refika Aditama, Bandung, 2011 